\title{
Pengembangan Instrumen Penilaian Kualitas Layanan Rumah Sakit
}

\section{Developing Hospital Service Quality Assessment Instrument}

\author{
Dwi Kartikasari , Aryo Dewanto ${ }^{1}$, Maya Syahria $S^{2}$ \\ ${ }^{1}$ Program Studi Magister Manajemen Rumah Sakit Fakultas Kedokteran Universitas Brawijaya Malang \\ ${ }^{2}$ Rumah Sakit Umum Daerah Bhakti Dharma Husada Surabaya
}

\begin{abstract}
ABSTRAK
Pengukuran kualitas pelayanan secara berkala merupakan titik masuk dalam peningkatan mutu berkelanjutan. Penelitian ini bertujuan untuk mengembangkan instrumen penilaian kualitas layanan. Instrumen dikembangkan berdasarkan kuesioner kualitas layanan yang disusun oleh Padma yang selanjutnya dianalisis untuk melihat faktor pembentuk dimensi kualitas layanan. Data dikumpulkan menggunakan kuesioner delapan dimensi kualitas layanan yang diukur berdasarkan persepsi pasien menggunakan skala Likert 5 poin. Kuesioner diberikan pada 84 pasien di Instalasi Rawat Jalan, Instalasi Rawat Inap dan Instalasi Gawat Darurat (IGD). Analisis data menggunakan Confirmatory Analysis Factor (CFA) dengan uji kecukupan sampel KMO MSA>0,50 pada semua dimensi dengan signifikasi bartlett test 0,00 (Sign<0,05). Ekstraksi dan rotasi faktor dilakukan hingga terbentuk satu komponen pada satu dimensi. Hasil penelitian ini menunjukkan bahwa dari 8 dimensi kualitas layanan yang terdiri 59 item pernyataaan, setelah dilakukan analisis menggunakan Confirmatory Factor Analysis (CFA) dengan loading factor diatas 0,50, menghasilkan 3-7 item pada masing-masing dimensi sehingga didapatkan 37 item. Dimensi infrastruktur dibentuk oleh 5 item, kualitas personil dibentuk oleh 6 item, proses perawatan klinis dibentuk oleh 4 item, prosedur administrasi dibentuk oleh 4 item, indikator keselamatan pasien dibentuk oleh 3 item, citra rumah sakit dibentuk oleh 5 item, tanggung jawab sosial dibentuk oleh 3 item, dan kepercayaan terhadap rumah sakit dibentuk oleh 7 item.
\end{abstract}

Kata Kunci: Kepuasan pasien, kualitas layanan rumah sakit, kuesioner

\begin{abstract}
Periodic measurement of service quality is the focal point for a continuous quality improvement. This research aims to develop a service quality assessment instrument. The instrument was developed based on service quality questionnaire developed by Padma and analyzed to determine the factors forming the dimensions of service quality. Data were collected using a questionnaire on eight dimensions of service quality as measured by patient perception using a 5-point Likert scale. Questionnaires were administered to 84 patients in the Outpatient unit, Inpatient unit, and Emergency Room (ER). The data were analyzed using Confirmatory Factor Analysis (CFA) with KMO sample adequacy test MSA $>0,50$ in all dimensions with Bartlett test significance 0,00 (Sign<0,05). Extraction and factor rotation were done so that one component is formed in each dimension. The results of this study show that from eight dimensions of service quality consisting of 59 items, when loading factor was set with 0,50 or above, generates 3-7 items in each dimension with a total of 37 items. Infrastructure dimension was composed by 5 items, the quality of personnel was composed by 6 items, the process of clinical care was composed by 4 items, the administrative procedures were composed by 4 items, patient safety indicators were composed by 3 items, hospital image was composed by 5 items, social responsibility was composed by 3 items, and trust in the hospital was composed by 7 items.
\end{abstract}

Keywords: Hospital service quality, patient satisfaction, questionnaire

Jurnal Kedokteran Brawijaya, Vol. 28, Suplemen No. 1, 2014: Dwi Kartikasari. Program Studi Magister Manajemen Rumah Sakit Fakultas Kedokteran Universitas Brawijaya Malang, Jl. Veteran Malang 65142 Tel. (0341) 568989 Email: kartikasaridwi78@yahoo.com 


\section{PENDAHULUAN}

Pasien sebagai pelanggan rumah sakit merupakan pusat dari layanan yang diberikan oleh rumah sakit. Keselamatan dan kepuasan pasien menjadi hal yang utama dalam layanan rumah sakit. Rumah sakit dikatakan mempunyai kinerja yang baik apabila rumah sakit dapat memberikan pelayanan yang dapat memberikan kepuasan dan memenuhi kebutuhan pelanggan sesuai dengan harapan (1). Parasuraman et al mendefinisikan penilaian kualitas pelayanan sebagai sikap individu secara umum terhadap kinerja perusahaan yang berhubungan dengan keunggulan (superiority) dari suatu pelayanan atau jasa (2).

Kualitas pelayanan merupakan pertimbangan mendasar bagi pelanggan untuk memutuskan akan memakai suatu produk barang atau jasa atau tidak. Menurut Donabedian, kualitas mutu pelayanan adalah suatu pelayanan yang diharapkan dapat meningkatkan atau memaksimalkan kesejahteraan pelanggan dan memberikan kepuasan pelanggan (3). Donabedian dalam Padma menggolongkan kualitas layanan menjadi dua, yaitu technical quality dan functional quality. Technical quality berkaitan dengan kesesuaian pada spesifikasi professional, sedangkan functional quality adalah kualitas yang berkaitan dengan bagaimana layanan kesehatan yang diberikan pada pasien (4).

Minat pasien untuk memilih sebuah fasilitas pelayanan biasanya berdasarkan pertimbangan pada 7 (tujuh) C menurut Ireland yaitu care, caring, comfort, convenience, curative, cope dan cost. Care meliputi kemampuan yang dimiliki rumah sakit, caring berupa hubungan antara pemberi layanan kesehatan kepada pasien, comfort berhubungan dengan sifat hotel seperti pelayanan makanan, fasilitas rawat inap. Convenience berhubungan dengan kemudahan alur rumah sakit serta penjadwalan waktu pelayanan, curative adalah kemampuan rumah sakit untuk menyembuhkan. Cope berupa hal yang dapat membantu pasien menyesuaikan diri, dan cost, adalah efisiensi dalam menyelenggarakan administrasi (5).

Kinerja RSUD Bhakti Dharma Husada dalam memberikan pelayanan kepada masyarakat dalam 3 tahun ini secara umum bagus bila dilihat dari peningkatan jumlah kunjungan Instalasi Gawat Darurat (IGD), Instalasi Rawat jalan dan Instalasi Rawat Inap. Pencapaian Bed Occupancy Rate (BOR) secara umum selama 3 tahun mengalami peningkatan. Selain itu, survei Indeks Kepuasan Masyarakat (IKM) yang dilakukan pada tahun 2012 oleh PT. Kokek mendapatkan hasil 78,61 yang termasuk dalam kategori baik.

Meskipun kinerja RSUD Bhakti Dharma Husada secara umum bagus, terdapat beberapa hal yang harus mendapatkan perhatian manjemen RSUD Bhakti Dharma Husada yaitu adanya kecenderungan peningkatan angka pulang paksa pada instalasi rawat inap pada tahun 2013 dan adanya tren BOR yang fluktuatif pada bulan-bulan tertentu pada tahun 2013. Angka pulang paksa dan BOR yang fluktuatif tidak selalu berhubungan dengan kualitas layanan. Meskipun demikian sebagai rumah sakit yang baru berdiri tiga tahun dan berupaya menjadi rumah sakit pilihan pelanggan, maka persepsi pasien terhadap kualitas layanan dan kepuasan pasien harus dipertahankan dan dievaluasi secara berkala. Pengembangan instrumen penilaian kualitas pelayanan berdasarkan karakter pengguna jasa layanan merupakan langkah awal dalam peningkatan mutu berkelanjutan. Studi ini bertujuan untuk menyusun instrumen untuk mengukur kepuasan dan persepsi pasien terhadap kualitas layanan RSUD Bhakti Dharma Husada Surabaya.

\section{METODE}

Penelitian ini dilakukan dengan survei kepada pasien RSUD Bhakti Dharma Husada melalui kuesioner. Kuesioner terdiri dari 59 item pertanyaan, dari delapan dimensi kualitas layanan berdasarkan kuesioner yang digunakan oleh Padma yang telah dimodifikasi (4). Pengukuran pada kuesioner tersebut mengunakan skala Likert lima poin yaitu mulai 1 (sangat tidak setuju) hingga 5 (sangat setuju).

Populasi dari penelitian ini adalah seluruh pasien RSUD Bhakti Dharma Husada yang ada di Instalasi Gawat Darurat (IGD), Instalasi Rawat Jalan (IRJA), dan Instalasi Rawat Inap (IRNA). Jumlah rata-rata kunjungan pada ketiga unit tersebut pada tahun 2012 adalah sebanyak 3007 orang Pengambilan sampel dilakukan secara purposive pada tanggal 25 November 2013 sampai 11 Desember 2013. Kriteria pasien yang diambil sebagai sampel adalah pasien rawat inap minimal sudah menjalani rawat inap selama 2 hari dan akan pulang atau Keluar Rumah sakit (KRS) dan dapat berkomunikasi dengan baik. Pasien anak-anak diwakili oleh orang tua atau keluarganya sebanyak 22 orang. Variabel pada penelitian ini dikembangkandari dimensi kualitas layanan menurut Padma, yang terdiri dari infrastruktur, kualitas personil, proses perawatan klinis, prosedur administrasi, indikator keselamatan, citra rumah sakit, tanggung jawab sosial rumah sakit, dan kepercayaan rumah sakit.

Data dianalisis dengan menggunakan analisis faktor konfirmatori (Confirmatory Factor Analysis-CFA). Analisis faktor konfirmatori digunakan untuk mereduksi item pernyataan yang terdapat pada variabel dimensi kualitas layanan, sehingga akan terbentuk item pernyataan yang merupakan penjelas atau pembentuk dimensi kualitas layanan tersebut. Salah satu tujuan analisis faktor adalah mereduksi jumlah item dengan cara mirip seperti pengelompokan variabel (6). Pada analisis faktor konfirmatori, kecukupan sampel diuji dengan memperhatikan Matriks Sample Analysis (MSA). Matriks korelasi dan ekstraksi faktor digunakan untuk mendapatkan loading factor dan faktor rotasi (7).

Penilaian kecukupan sampel dilakukan dengan KaiserMeyer-Oikin measure of sampling adequacy (KMO MSA) dan Barlett test of sphericity. Hasil KMO MSA dan Barlett test menunjukkan bahwa sampel yang digunakan sudah dapat digunakan dengan angka KMO MSA diatas 0,50 ( $K M O M S A>0,50$ ) pada semua dimensi dengan signifikansi Barlett test 0,00 (Sign<0,05). Hasil ini menunjukkan bahwa variabel dan sampel yang ada dapat dianalisis dengan analisis faktor.

Setelah uji kecukupan sampel memenuhi syarat selanjutnya dilakukan ekstraksi dan rotasi faktor. Ekstraksi faktor digunakan untuk mereduksi data dari beberapa indikator untuk mengahasilkan faktor yang lebih sedikit dan dapat menjelaskan korelasi antar indikator. Ekstraksi faktor menjelaskan jumlah faktor yang terbentuk dengan melihat nilai eigenvalue. Bila nilai eigenvalue 1, maka indikator yang ada dapat menjelaskan faktor dengan baik.

Ekstraksi faktor menggunakan principal component analysis, mereduksi item pernyataan sampai terbentuk satu group item pernyataan yang merupakan pembentuk 
dimensi kualitas layanan. Faktor rotasi dilakukan untuk memperjelas faktor utama yang diperoleh (8), faktor rotasi dilakukan dengan metode varimax. Ekstraksi dan faktor rotasi akan diulang apabila terdapat indikator yang mempunyai loading factor kurang dari 0,50, dengan menghilangkan indikator yang mempunyai faktor loading yang rendah tersebut. Ekstraksi dan faktor rotasi diulang hingga terbentuk satu komponen pada setiap dimensi.

\section{HASIL}

Kuesioner yang dibagikan sebanyak 92 kuesioner. Dari seluruh kuesioner yang dibagikan, terdapat 8 kuesioner yang tidak diisi lengkap, sehingga kuesioner yang dapat digunakan adalah sebanyak 84 kuesioner. Karakteristik responden RSUD Bhakti Dharma Husada disajikan pada Tabel 1. Responden pada penelitian ini sebagian besar perempuan (70\%), dalam usia produktif (75\%), dengan pendidikan SMU (73\%). Pendapatan responden sebagian besar di atas Rp. 1.500.000,- (70\%) dengan responden terbanyak (59\%) mempunyai pendapatan antara $\mathrm{Rp}$. 1.500.000,- s/d Rp. 4.500.000,-. Responden yang berobat ke RSUD Bhakti Dharma Husada hampir merata antara pasien dengan pembiayaan sendiri (52\%) dan pasien dengan asuransi (48\%).

Tabel 1. Karakteristik responden

\begin{tabular}{|c|c|c|c|}
\hline \multicolumn{2}{|c|}{ Karakteristik } & \multirow{2}{*}{$\begin{array}{c}\begin{array}{c}\text { Jumlah } \\
\text { (Orang) }\end{array} \\
25\end{array}$} & \multirow{2}{*}{$\begin{array}{c}\text { Persentase } \\
(\%)\end{array}$} \\
\hline Jenis Kelamin & Laki & & \\
\hline & Perempuan & 59 & 70 \\
\hline \multirow[t]{2}{*}{ Usia } & $17-22$ & 5 & 6 \\
\hline & $23-28$ & 10 & 12 \\
\hline \multirow[t]{9}{*}{ Karakteristik } & $29-34$ & 11 & 13 \\
\hline & $35-40$ & 14 & 17 \\
\hline & $41-45$ & 8 & 10 \\
\hline & $46-50$ & 10 & 12 \\
\hline & $51-55$ & 4 & 5 \\
\hline & $56-60$ & 2 & 2 \\
\hline & $61-65$ & 8 & 10 \\
\hline & $66-70$ & 7 & 8 \\
\hline & $71-75$ & 2 & 2 \\
\hline \multirow[t]{4}{*}{ Pendidikan } & SMU & 61 & 73 \\
\hline & Diploma & 2 & 2 \\
\hline & Sarjana & 14 & 17 \\
\hline & S2/S3 (pascasarjana) & 5 & 6 \\
\hline \multirow[t]{6}{*}{ Pendapatan } & $<1.500 .000$ & 25 & 30 \\
\hline & $>1.500 .000-2.500 .000$ & 24 & 29 \\
\hline & $>2.500 .000-3.500 .000$ & 17 & 20 \\
\hline & $>3.500 .000-4.500 .000$ & 8 & 10 \\
\hline & $>4.500 .000-5.500 .000$ & 6 & 7 \\
\hline & $>5.500 .000$ & 1 & 1 \\
\hline \multirow[t]{5}{*}{ Pembiayaan } & Biaya Sendiri & 44 & 52 \\
\hline & ASKES & 16 & 19 \\
\hline & Jamkesmas & 14 & 17 \\
\hline & SKTM & 6 & 7 \\
\hline & Asuransi Lain & 4 & 5 \\
\hline
\end{tabular}

\section{Analisis Faktor}

Hasil uji validitas dan realibilitas kuesioner kualitas layanan RSUD Bhakti Dharma Husada menunjukkan bahwa seluruh item pernyataan valid $(0,01)$. Realibilitas kuesioner termasuk dalam kategori tinggi (alpha cronbach $=0,96$ ).
Analisa data yang digunakan adalah analisis faktor. Ekstraksi faktor menggunakan principal component analysis (PCA), jumlah faktor yang ditetapkan adalah satu, apabila nilai loading factor lebih dari 0,5 berarti variabel tersebut dapat menjelaskan faktor yang terbentuk. Semakin tinggi loading factor sebuah indikator, maka dapat dikatakan bahwa indikator tersebut merupakan pembentuk faktor yang semakin kuat. Loading factor item hasil analisis faktor konfirmatori disajikan pada Tabel 2. Seluruh item dengan loading factor lebih dari 0,5 dapat dikatakan sebagai itempembentuk variabel, namun bila dipilih loading factor dengan minimal 0,7 maka setiap dimensi kualitas akan memiliki 3-5 item seperti yang disajikan pada Tabel 2 dengan cetak tebal.

Tabel 2. Hasil analisis faktor item instrumen kualitas layanan RS BDH

\begin{tabular}{|c|c|c|}
\hline Dimensi & Item & $\begin{array}{l}\text { Loading } \\
\text { Factor }\end{array}$ \\
\hline Infrastruktur & Ketersediaan fasilitas ruang periksa & 0,825 \\
\hline \multirow[t]{6}{*}{ KMO MSA 0,796 } & Kebersihan dan kerapihan fasilitas & 0,809 \\
\hline & ruang periksa Kenyamanan & 0,763 \\
\hline & Keamanan & 0,670 \\
\hline & alat berfungsi baik & 0,623 \\
\hline & Ketersediaan fasilitas ruang tunggu & 0,484 \\
\hline & Desain menarik & 0,447 \\
\hline Kualitas personil & Perawat ada saat dibutuhkan & 0,838 \\
\hline \multirow[t]{5}{*}{ KMO MSA 0,797 } & Kerjasama dokter dan perawat & 0,820 \\
\hline & Perawat terampil & 0,761 \\
\hline & Perawat ramah & 0,758 \\
\hline & Visite tepat waktu & 0,742 \\
\hline & Dokter ramah & 0,505 \\
\hline Proses perawatan klinis & Tindakan cepat jika komplikasi & 0,823 \\
\hline \multirow[t]{3}{*}{ KMO MSA 0,766 } & Diagnosa tepat & 0,817 \\
\hline & Perawatan sesuai dengan yang diinginkan & 0,737 \\
\hline & Penjelasan prosedur pemeriksaan & 0,714 \\
\hline Prosedur administratif & Prosedur pemeriksaan mudah & 0,769 \\
\hline \multirow[t]{3}{*}{ KMO MSA 0,751 Sig 0,000 } & Prosedur pembayaran mudah & 0,747 \\
\hline & Ketegasan jadwal kunjungan/pelayanan & 0,722 \\
\hline & Kemudahan konsultasi & 0,695 \\
\hline \multirow{2}{*}{$\begin{array}{l}\text { Indikator keselamatan } \\
\text { pasien }\end{array}$} & Keselamatan pasien & 0,854 \\
\hline & Perilaku higienis karyawan & 0,818 \\
\hline KMO MSA 0,678 Sig 0,000 & Lingkungan bebas infeksi & 0,783 \\
\hline Citra rumah sakit & Karyawan Jujur & 0,855 \\
\hline \multirow[t]{4}{*}{ KMO MSA 0,850 Sig 0,000} & Reputasi baik & 0,830 \\
\hline & Karyawan sesuai kode etik & 0,795 \\
\hline & Layanan lebih baik & 0,788 \\
\hline & Karyawan tulus & 0,759 \\
\hline Tanggung Jawab Sosial RS & Layanan pasien tidak mampu & 0,817 \\
\hline \multirow[t]{2}{*}{ KMO MSA 0,669 Sig 0,000 } & Tidak membedakan status & 0,806 \\
\hline & Menjunjung etika pelayanan & 0,761 \\
\hline Kepercayaan terhadap RS & Pemeriksaan sesuai kebutuhan & 0,858 \\
\hline \multirow[t]{6}{*}{ KMO MSA 0,846 Sig 0,0000} & Kebutuhan pasien yang utama & 0,798 \\
\hline & Tagihan akurat & 0,779 \\
\hline & Ditangani cepat & 0,735 \\
\hline & Tidak melebihi kebutuhan & 0,655 \\
\hline & Kerahasiaan dijamin & 0,628 \\
\hline & Proritas keselamatan pasien & 0,533 \\
\hline
\end{tabular}

Keterangan: Cetak tebal merupakan faktor pembentuk kuat

Item yang dicetak tebal pada Tabel 2 menunjukkan item yang merupakan pembentuk faktor yang kuat pada setiap 
faktor (atau disebut dimensi) kualitas layanan. Item pembentuk dimensi infrastruktur yang kuat adalah ketersediaan ruang periksa, kebersihan dan kerapian ruang periksa, dan kenyamanan. Item dengan loading factor lebih dari 0,50 , yaitu keamanan $(0,67)$ dan alat berfungsi dengan baik $(0,63)$ juga merupakan pembentuk dimensi infrastruktur dan dapat dipertimbangkan sebagai item instrumen di RS Bhakti Dharma Husada Surabaya.

Dimensi kualitas personil yang diukur pada instrumen di RSUD Bhakti Dharma Husada dikhususkan pada kualitas perawat dan dokter. Item pembentuk dimensi kualitas personil yang kuat (dengan loading factor di atas 0,7 ) adalah faktor ketersediaan perawat, kerjasama dokter dan perawat, keterampilan perawat, keramahan perawat, dan ketepatan waktu visite dokter. Keramahan dokter (loading factor 0,5 ) juga merupakan pembentuk dimensi kualitas personil yang dapat dimasukkan sebagai instrumen pada dimensi kualitas personil. Item pembentuk dimensi proses perawatan klinis yang mempunyai loading factor 0,7 adalah kecepatan penanganan apabila ada komplikasi, ketepatan diagnose, kesesuaian perawatan yang diinginkan dan kejelasan prosedur pemeriksaan.

Pada dimensi prosedur administratif, item pembentuk yang kuat dengan loading factor 0,7 adalah faktor prosedur pemeriksaan yang mudah, prosedur pembayaran yang mudah dan ketegasan jadwal kunjungan dan pelayanan. Item kemudahan konsultasi $(0,695)$ juga merupakan faktor pembentuk dimensi prosedur administratif sehingga dapat dipertimbangkan sebagai item instrumen di RSUD Bhakti Dharma Husada.

Item pembentuk pada dimensi indikator keselamatan yang kuat (dengan loading factor diatas 0,7 ) adalah faktor keselamatan pasien, perilaku higienis karyawan dan lingkungan yang bebas infeksi. Pada dimensi citra rumah sakit, item pembentuk dimensi yang kuat dengan loading factor diatas 0,7 adalah faktor kejujuran karyawan, reputasi rumah sakit yang baik, pelayanan yang sesuai kode etik, pelayanan yang lebih baik dibandingkan tempat lain, dan ketulusan karyawan

Item pembentuk yang kuat pada dimensi tanggung jawab sosial rumah sakit dengan loading factor diatas 0,7 adalah faktor ketersediaan pelayanan untuk pasien tidak mampu, pelayanan yang tidak membeda-bedakan status dan pelayanan yang menjunjung etika. Pada dimensi kepercayaan rumah sakit, item pembentuk dimensinya yang kuat (loading factor $=0,7$ ) adalah faktor kesesuaian pemeriksaan, pelayaan yang mengutamakan kebutuhan pasien, keakuratan tagihan dan kecepatan penanganan pasien. Pemeriksaan yang tidak melebihi kebutuhan $(0,655)$. Jaminan kerahasiaan pasien $(0,628)$ dan prioritas keselamatan pasien $(0,533)$ juga merupakan faktor pembentuk dimensi kepercayaan rumah sakit yang dapat dipertimbangkan sebagai item instrumen di RSUD Bhakti Dharma Husada.

\section{DISKUSI}

Salah satu instrumen untuk menilai kualitas layanan yang sering digunakan SERVQUAL. Pada perkembangannya, banyak peneliti yang mengembangkan kerangka kerja untuk membentuk dimensi kualitas layanan. Dugiralla mengembangkan kerangka konsep dimensi kualitas layanan terdiri dari tujuh dimensi, yaitu: infrastruktur, kualitas personil, proses perawatan klinis, prosedur administrasi, indikator keselamatan, keseluruhan pengalaman medis dan tanggung jawab sosial. Penelitian yang dilakukan oleh Padma pada tahun 2009 mengembangkan kerangka konsep Dugiralla, dengan menghilangkan dimensi pengalaman perawatan medis secara keseluruhan dan dimasukkan pada proses perawatan klinis serta menambahkan citra rumah sakit, dan kepercayaan rumah sakit sebagai dimensi kualitas layanan, sehingga terbentuk kerangka konsep delapan dimensi kualitas layanan yang meliputi: infrastruktur, kualitas personil, proses perawatan klinis, prosedur administrasi, indikator keselamatan, citra rumah sakit, tanggung jawab sosial dan kepercayaan rumah sakit $(4,22)$

\section{Infrastruktur}

Dimensi infrastruktur merupakan dimensi kualitas layanan yang mempunyai wujud nyata, yang disebut sebagai lingkungan fisik. Hasil dari penelitian ini faktor yang membentuk dimensi infrastruktur adalah faktor ketersediaan ruang periksa, kebersihan dan kerapian ruang periksa, kenyamanan, dan keamanan. Hal ini sesuai dengan beberapa literatur yang menjelaskan tentang dimensi infrastruktur. Parasuraman dalam dimensi SERVQUAL juga memasukkan lingkungan fisik sebagai salah satu dimensi kualitas layanan yang disebut dengan tangible (9). Penelitian Reidenbach, Smallwood, dan Otani Kurz menggunakan dimensi lingkungan fisik dan kenyamanan lingkungan dalam studi mereka masingmasing, untuk menunjukkan fasilitas fisik dalam proses pemberian layanan $(10,11)$.

\section{Kualitas Personil}

Dimensi kualitas personil merupakan dimensi kualitas layanan yang berhubungan dengan komunikasi antara pasien dengan dokter, perawat, paramedis dan staf administrasi sebagai penyedia layanan. Pada penelitian ini dimensi kualitas personil dibentuk oleh faktor ketersediaan perawat, kerjasama dokter dan perawat, ketrampilan perawat, keramahan perawat, dan ketepatan waktu visite dokter, keramahan dokter, hal ini sesuai dengan beberapa teori dan penelitian tetang dimensi kualitas personil. Parasuraman et al, menggunakan istilah empati, responsive dan reliability untuk menggambarkan kualitas personil dalam dimensi SERVQUAL nya (9). Hasin et al menggunakan faktor sopan santun, hormat dan peduli untuk mewakili kualitas personil mereka (12). Perbedaan istilah atau faktor yang digunakan pada dimensi kualitas personil pada dasarnya mempunyai konteks yang sama yaitu mengacu pada terbentuknya komunikasi yang baik antara pasien dengan semua karyawan yang terlibat dalam proses pemberian layanan. Penelitian yang dilakukan oleh Curry dan Sinclair, menemukan bahwa pasien merasa dihargai dan aman selama menjalani pengobatan di rumah sakit apabila dilayani oleh karyawan yang ramah, mempunyai kepercayaan diri dan pengetahuan yang tinggi untuk dapat menjelaskan atau menjawab semua pertanyan pasien. Hal inilah yang merupakan harapan tertinggi dari pasien (13). Penelitian yang dilakukan oleh O'Connor menyatakan komunikasi intensif antara dokter dan pasien mempunyai dampak yang signifikan terhadap kepuasan pelanggan (14). Carman menyatakan bahwa perawat merupakan layanan inti dari rumah sakit, sehingga komunikasi yang baik antara perawat dan pasien merupakan hal penting yang harus diperhatian oleh penyedia layanan (15). Penelitian yang dilakukan Andaleeb menyatakan interaksi 
antara pasien dan staf dalam hal komunikasi, kompetensi dan sikap staf menpunyai dampak yang signifikan terhadap kepuasan pasien (16).

\section{Proses Perawatan Klinis}

Proses perawatan klinis menurut Padma meliputi primary quality; technical quality, proses pengobatan dan hasilnya, kehandalan (reliability), dan pemahaman penyakit (understanding of illness) (4). Pada penelitian ini yang termasuk pembentuk dimensi proses perawatan klinis ini adalah kecepatan penanganan apabila ada komplikasi, ketepatan diagnosa, kesesuaian perawatan yang diinginkan dan kejelasan prosedur pemeriksaan. Proses perawatan klinis merupakan dimensi inti dari kualitas layanan, menurut Lewis proses perawatan klinis mengacu pada proses pemberian layanan terkait dengan manajemen pelayanan dan peran staf pemberi layanan (4). Gronroos dalam penelitiannya berpendapat bahwa proses perawatan klinis ini merupakan kualitas teknis dari pelayanan rumah sakit (17). Carman menggunakan proses asuhan keperawatan dan proses pengobatan serta hasil pengobatan dokter sebagai aspek teknis dalam proses pelayanan rumah sakit (15). Zeithaml et al, menggunakan istilah proses pengobatan dan hasil dari proses pengobatan sebagai aktifitas yang terdapat dalam proses perawatan klinis (9). Baldwin dan Sohal, dalam penelitiannya tentang kualitas pelayanan dalam perawatan gigi menyatakan proses pemberian layanan yang nyaman dalam mengatasi rasa takut dan kecemasan pasienmempunyai pengaruh yang signifikan terhadap persepsi pasien (18).

\section{Prosedur Administrasi}

Prosedur administrasi merupakan prosedur pelayanan mulai dari masuk, tinggal atau dirawat hingga keluar atau setelah perawatan. Prosedur pelayanan yang termasuk dalam prosedur administrasi ini adalah hal-hal berkaitan dengan prosedur administratif, prosedur pemeriksaan dan ketepatan layanan. Pada penelitian ini yang termasuk dalam prosedur administrasi adalah faktor prosedur pemeriksaan yang mudah, prosedur pembayaran yang mudah, ketegasan jadwal kunjungan serta pelayanan dan kemudahan konsultasidengan dokter. Penelitian yang dilakukan oleh Sureshchandar et al, menyatakan bahwa prosedur administrasi yang efisien dan terstandarisasi sehingga memudahkan pasien, dapat membuat pasien menghargai pelayanan yang diberikan oleh rumah sakit secara lebih baik (19). Penelitian yang dilakukan oleh Reidenbach dan Smallwood, menyatakan waktu tunggu merupakan salah satu dimensi kualitas layanan, sedangkan Rose dkk menggunakan istilah waktu akses sebagai dimensi kualitas layanan $(10,20)$. Baldwin dan Sohal dalam penelitiannya menyatakan bahwa pemberian layanan yang tepat waktu mempengaruhi persepsi pasien secara signifikan.

\section{Indikator Keselamatan}

Dimensi indikator keselamatan dalam kualitas layanan mengacu pada prinsip rumah sakit harus dapat memberikan pelayanan yang aman terhadap pasien sesuai dengan filosofi Hipocrates "Do No Harm ". Pada penelitian ini faktor yang membentuk dimensi indikator keselamatan ini adalah faktor keselamatan pasien, perilaku higienis karyawan dan lingkungan yang bebas infeksi. Penelitian terdahulu yang berhubungan dengan keselamatan pasien diantaranya adalah Poon dan Rendah dalam penelitiannya pada kualitas layanan perhotelan menyatakan bahwa keselamatan dan keamanan merupakan dimensi penting kualitas layanan (4). Boshoff dan Gray menyatakan bahwa semua karyawan rumah sakit harus menunjukkan kepeduliannya kepada pasien dan memastikan bahwa pasien merasa aman selama mereka berada di rumah sakit. Massaro menyatakan bahwa pimpinan layanan kesehatan harus memastikan dan menjadikan kemanan pasien sebagai salah satu tujuan utama organisasi dan bisnis (21). Dugiralla dalam penelitiannya menyatakan bahwa ketersediaan layanan dan prosedur pemeriksaan yang aman merupakan hal yang harus diperhatikan oleh rumah sakit dalam meningkatkan kualitas kesehatan dan hidup pasien (22). Beberapa penelitian yang terdahulu telah menyatakan tentang pentingnya pelayanan yang mengacu pada keselamatan pasien atau pelanggan tetapi belum ada yang menggunakan indikator keselamatan sebagai salah satu dimensi kualitas layanan. Sejauh ini baru Dugiralla dan Padma yang secara spesifik telah memasukkan indikator keselamatan sebagai dimensi kualitas layanan.

\section{Image Rumah Sakit}

Citra atau image rumah sakit merupakan salah satu hal yang menjadi pertimbangan bagi pasien untuk menggunakan layanan sebuah rumah sakit. Hasil penelitian ini faktor yang membentuk dimensi image rumah sakit adalah faktor kejujuran karyawan, reputasi rumah sakit yang baik, pelayanan yang sesuai kode etik, pelayanan yang lebih baik dibandingkan tempat lain, dan ketulusan karyawan Gronroos dalam penelitiannya menyatakan pentingnya image dalam konsep kualitas layanan, dan dapat digunakan sebagai filter dalam persepsi kualitas layanan selain dimensi kualitas teknis dan fungsional (17). Caruana, Hong, dan Goo menemukan bahwa image perusahaan mempunyai peran penting dalam menyampaikan produk layanan kepada pelanggan dan berpengaruh terhadap kepuasan pelanggan $(23,24)$. Padma dalam penelitiannya menyatakan bahwa image mempunyai pengaruh terhadap harapan pelanggan oleh karena itu untuk membuat pelanggan memiliki harapan yang realistis maka reputasi rumah sakit harus dianggap sebagai unsur kualitas layanan (4).

\section{Tanggung Jawab Sosial}

Sebuah perusahaan dalam perundang-undangan mempunyai kewajiban tanggung jawab sosial kepada masyarakat, dan tanggung jawab sosial merupakan indikator penting dari kualitas layanan. Hasil dari penelitian ini faktor yang membentuk dimensi tanggung jawab sosial adalah faktor ketersediaan pelayanan untuk pasien tidak mampu, pelayanan yang tidak membedabedakan status dan pelayanan yang menjunjung etika. Malcolm Baldrige National Quality Award (MBNQA) pada tahun 2007 menegaskan bahwa tanggung jawab sosial merupakan indikator penting dari kualitas layanan (4). Chiu dan Lin mengamati bahwa pelanggan akan menghargai kualitas pelayanan lebih baik apabila perusahaan dapat memenuhi kebutuhan aktualisasi diri dari pelanggan, misal ketika pelanggan menyadari bahwa ia ikut berpartisipasi dalan kegiatan sosial, begitu pula menurut Sureshchandar et al dalam penelitiannya menyatakan bahwa pelanggan akan menghormati dan menghargai sebuah organisasi atau perusahaan yang mempunyai tanggung jawab sosial $(4,19)$. Padma dalam penelitiannya menyatakan harapan masyarakat terhadap kualitas layanan rumah sakit tidak hanya pada pemberian layanan yang baik, tetapi juga pelayanan yang adil dari 
penyedia layanan (4).

\section{Kepercayaan Rumah Sakit}

Kepercayaan pelanggan terhadap produk jasa akan menimbulkan minat pelanggan untuk menggunakan atau membeli kembali produk tersebut pada masa yang akan datang. Hasil penelitian ini faktor yang membentuk dimensi kepercayaan rumah sakit adalah faktor kesesuaian pemeriksaan, pelayanan yang mengutamakan kebutuhan pasien, keakuratan tagihan, kecepatan penanganan pasien, pemeriksaan yang tidak melebihi kebutuhan, jaminan kerahasiaan pasien dan prioritas keselamatan pasien. Parasuraman et al dan Sureshchandar et al menyatakan bahwa kemampuan rumah sakit menyediakan layanan seperti yang dijanjikan merupakan aspek penting dari pelayanan $(9,19)$. Padma mengungkapkan bahwa kepercayaan rumah sakit dapat diukur dengan pasien merasa merasa nyaman, aman, dan kepercayaan ini berperan dalam evaluasi kualitas pelayanan secara keseluruhan. Boshoff dan Gray menyatakan bahwa semua karyawan rumah sakit harus menunjukan kepeduliannya kepada pasien, memastikan

\section{DAFTAR PUSTAKA}

1. Atihuta JA, Pasinringa SA, dan Bahar Burhanuddin. Analisis Faktor yang Mempengaruhi Kinerja Mutu Pelayanan di RSUD Dr. M. Haulussy Ambon. [Tesis]. Universitas Hasanudin, Makasar. 2011.

2. Nurcaya IN. Analisis Kualitas Pelayanan Rumah Sakit di Provinsi Bali. Piramida. 2008; 4(2).

3. Donabedian A. Quality Assessment and Assurance: Unity of Purpose, Diversity of Means. Inquiry. 1988; 25(1): 173-192.

4. Padma P, Rajendran C, and Sai LP. A Conceptual Framework of Service Quality in Healthcare: Perspectives of Indian Patients and their Attendants. Benchmarking: An International Journal. 2009; 16(2): 157-191.

5. Wijono D. Manajemen Mutu Pelayanan Kesehatan; Teori, Strategi, dan Aplikasi. Surabaya: Airlangga University Press; 1999.

6. Solimun. Structural Equation Modeling dan Lisrel. Malang: Fakultas MIPA Universitas Brawijaya; 2003.

7. Huda S. Faktor-faktor yang Mempengaruhi Bidan Memilih Rumah Sakit Sebagai Tempat Rujukan Kasus Ibu Hamil Resiko Tinggi (Survei Pada Bidan PTT Desa di Wilayah Pengembangan Kepanjen).[Tesis]. Universitas Brawijaya, Malang. 2011.

8. Widarjono A. Analisis Statistika Multivariat Terapan. Yogyakarta: Sekolah Tinggi Ilmu Manajemen YKPN; 2010.

9. Parasuraman A, ZeithamI VA, and Berry LI. Servqual: A Multiple-Item Scale for Measuring Consumer Perception of Service Quality. Journal of Retailing. 1988; 64(1): 12-40.

10. Reidenbach RE and Smalwood BS. Exploring Perceptions of Hospital Operations by a Modified SERVQUAL Approach. Journal of Healthcare Marketing. 1990; 10(4): 47-55.

11. Otani K and Kurz RS. "The Impact of Nursing Care and bahwa pasien merasa aman selama mereka berada di rumah sakit dan melakukan segalanya untuk mendapatkan kepercayaan pasien. Menurut Kim et al dalam Rofiq faktor yang membentuk kepercayaan adalah ability meliputi kompetensi, pegalaman, pengesahan institusional dan kemampuan dalam ilmu pengetahuan, benevolence meliputi perhatian, empati, keyakinan dan daya terima, integrity dilihat dari sudut kewajaran (fairness), pemenuhan (fulfillment), kesetiaan (loyalty), keterus terangan (honestly), keterkaitan (dependability) dan kehandalan (reliability).

Penelitian ini menghasilkan instrumen pengukuran kualitas pelayanan rumah sakityang dibentuk dari tujuh dimensi (infrastruktur, kualitas personil, proses perawatan klinis, prosedur administrasi, prosedur administrasi, keselamatan, citra dan tanggungjawab sosial) yang terdiri dari 37 item. Analisis faktor pada instrumen ini masih dilakukan satu kali dengan jumlah sampel yang terbatas. Instrumen yang dihasilkan harus diuji dengan sampel yang lebih banyak dan representatif agar menghasilkan instrumen yang lebih baik.

Other Healthcare Attributes in Hospitalized Patient Satisfaction and Behavioural Intentions". Journal of Health Care Management. 2004; 49(3): 181-196.

12. Hasin MAA, Seeluangsawat $R$, and Shareef MA. Statistical Measures of Customer Satisfaction for Health Care Quality Assurance: A Case Study. International Journal of Health Care Quality Assurance. 2001; 14(1): 6-14.

13. Curry A and Sinclair E. Assessing the Quality of Physiotherapy Services Using SERVQUAL. International Journal of Health Care Quality Assurance. 2002; 15(5): 97-205.

14. O'Connor SJ, Trinh HQ, and Shewchuk RM. Perceptual Gaps in Understanding Patient Expectations for Healthcare Service Quality. Health Care Management Review. 2000; 25(2): 7-23.

15. Carman JM. Patient Perceptions of Service Quality: Combining the Dimensions. Journal of Service Marketing. 2000; 14(4): 337-352.

16. Andaleeb S. Service Quality Perceptions and Patient Satisfaction: An Study of Hospitals in a Developing Country. Social Science and Medicine. 2001; 52(9): 1359-1370.

17. Gronroos C. Service Management and Marketing: A Customer Relationship Management Approach. 2nd Edition. California: Wiley; 2000.

18. Baldwin A and Sohal A. Service Quality Factors and Outcomes in Dental Care. Managing Service Quality. 2003; 13(3): 207-216.

19. Sureschchandar GS, Rajendran C, and Anantharaman RN. Determinants of Customer Perceived Service Quality: A Confirmatory Factor Analysis Approach. Journal of Services Marketing. 2002; 16(1): 9-34.

19. Rose RC, Uli J, Abdul M, and Ng KL. Hospital Service Quality: A Managerial Challenge. International Journal of Health Care Quality Assurance. 2004; 17(23): 146-159. 
20. Massaro R. Investing in Patient Safety: An Ethical and Business Imperative. Trustee. 2003; 56(6): 20-23.

21. Dugiralla D, Rajendran C, and Anantharaman RN. Patient Perceived Dimensions of Total Quality Service in Healthcare. Benchmarking: An International Journal. 2008; 15(5): 560-583.

22. Caruana A. Service Loyalty: The Effects of Service
Quality and the Mediating Role of Customer Satisfaction. European Journal of Marketing. 2002; 36(7/8): 811-828.

23. Hong SC and Goo YJJ. A Casual Model of Customer Loyalty in Professional Service Firms: An Empirical Study. International Journal of Management. 2004; 21(4): 531-541. 